\title{
Translanguaging, Diglossia and Bidialectalism in the Video Gamer Argot
}

\author{
RÓBERT ARNOLD-STEIN \\ Affiliation: University of Pannonia, Veszprém, Hungary \\ English and American Studies Institute \\ Email: robert.s.arnold@gmail.com \\ ILDIKÓ HORTOBÁGYI \\ Affiliation: University of Pannonia, Veszprém, Hungary \\ English and American Studies Institute \\ Email: ildiko@almos.uni-pannon.hu
}

\begin{abstract}
Video games have undergone an extensive technological advancement which has triggered a rapid shift in the role and potency the different media have gained in meeting infotainment needs. The widespread use of the internet has increased the frequency of video gaming among the youth thus promoting the emergence of linguistic material which could be instrumental in second language acquisition. The present paper aims to reveal the linguistic gains from virtual multicultural environments for video gamers in relation to their communication needs, a situation which rightfully characterizes them as bilinguals. Despite the continuing linguistic experimentation activities initiated by researchers, the video gamers' language utilization has not been paid much attention to as potential research domain in bi/multilingualism. The research has capitalized on the germane information of a cross sectional survey conducted on secondary school video gamer students in Hungary by investigating their language use habits derived from video game usage. The ample research scope results contribute to filling the linguistic gap of word formation methods, translanguaging, diglossia and bidialectalism by comparing the international and Hungarian instances of the video gamer argot. We also journey through the description, modelling, explanation of several processes which could happen within and outside the digital world as an illustration of language use in contact.
\end{abstract}

Keywords: gamer argot, code-switching, translanguaging, subcultural language development, language change 


\section{Introduction}

Nowadays, on the digital platforms the dividing line between written and oral communication is highly blurred. The communication strings on the chat platforms clearly show how e-literacy conveys the feeling of hearing the text due to the abundance of non-verbal elements (emoticons, using capital letters, doubling consonants and vowels, just to mention a few devices). We are investigating gamer argot according to its written occurrence and investigate how a simple playing activity can turn both into an infotainment and educational event. In terms of video game-related vocabulary, the gamers' language usage comprises only a narrow segment of the communication domains at first sight, although, since a gamer plays several types of video games or genres in her/his youth, to a certain extent their insight into the different accessed domains can be expanded by the importance of the timespan they spend in front of the screen. In addition, the sports video games also provide semi-authentic circumstances through their virtual environments, because the rules are identical to those of the real games. In this paper the term gamer argot refers to the lexis a young person has developed in the process of gaming. Due to the fact that a gamer plays several different types of games in one's youth or adolescence, one is able to collect and use this specific vocabulary in both online and offline (verbal) communication, consciously or unconsciously. Consequently, Grosjean's "complementary principle" of bilinguals (1997, p. 165) is compatible with the video gamer's English language application, because their English knowledge is being utilized and evolved complementary by playing on various game instruments.

\section{Video gamers as bilinguals}

Young video gamers, who have learnt their basic English in classrooms, having acquired their communicative proficiency during video gaming, ought to be considered rightfully as bilinguals (Crystal, 2008, p. 13), because they utilize the English language on a daily basis, thus, they are language users (Cook, 1993) rather than learners. In addition gamers frequently practice code switching and translanguaging by accessing words and features of other languages, in order to maximize their "communicative potential" in their "discursive practices" (Garcia, 2009, p. 112). However, linguists such as Schlobinski, do not consider the non-native English video game players as bilinguals because their language utilization is heterogenic and game dependent, thus it cannot be generalised (2000, quoted by Frehner, 2008, p. 27).

A speaker is bilingual who is able to function in two (or more) languages, either in monolingual or bilingual communities, in accordance with the sociocultural demands made on an individual's communicative and cognitive competence by these communities 
and by the individual herself, at the same level as native speakers. (Skutnabb-Kangas, 1984, p. 90; see also the discussion, pp. 89-93)

In this paper, we follow Crystal's and Cook's view complemented with Garcia and Klefgen, who proposed the notion of 'emergent bilinguals' in case of those students who "become bilingual, and are able to continue to function with their home language practices, as well as in English" (2018, p. 24). Video gamers have been researched from comprehensive linguistic points of view, such as vocabulary development, pragmatic language skills, code switching and borrowing, and willingness to communicate, as found by Sylvén \& Sundqvist (2012), Cabraya (2016), Hing (2015), Prensky (2006), Reinders, \& Wattana (2011), Horowitz (2019), etc. They all concluded that video gaming is a cutting-edge facilitator of language acquisition and social practice, and indeed carries characteristics of the new way of attaining and utilizing literacy, which was labelled "digilect" by Veszelszki (2013, p. 184) or "secondary orality" by Gee (2009, p. 7). Meanwhile, the gamers' social language usage is based on specialised jargon of the video games, which has already ramified into the subcultural usage, keeping the gamer argot diversified.

\section{Video gamer research}

During online gamer-gamer and in-game oral and written communication, the participants must employ terms from the particular (played) games from which they develop the gamer argot where the players adopt or eventually borrow words from a foreign language (English) in order to accurately express their personal interests. Thereby, the gamer's way of speaking ought to function in a bilingual mode (Grosjean, 1997, p. 163) because the utterer operates in two languages concurrently while gaming and at metalinguistic level when speaking about the games as well. Thus, besides their mother tongue, there must be game related words stored in the gamers' mental lexicon (Libben \& Goral, 2015) and ready to be used. Since video gamers are able to manage an outstanding number of game related phrases, which is also a prerequisite of their language proficiency, they transfer and use those video game related words in their everyday speech. Therefore, we may argue that creation of new, and the usage of borrowed gaming words, yields the gamer argot, which is an unexplored terrain to code-switching, translanguaging, diglossia or bidialectalism.

A considerable number of academic papers have endeavoured to collect and analyse words, expressions, emojis and abbreviations from written or spoken communication on digital devices (Chik, 2014; Benson \& Chik, 2011; Hilte et al., 2020; Strong, 2018; Veszelszki, 2013; Balogh, 2014; Veszelszki \& Parapatics, 2016; Veszelszki \& Balogh, 2019; Hortobágyi, 2017a, 2017b), in the aim to understand their linguistic behaviour better. 
All of them ascertain that the computer mediated language (CMC) has an intense effect on today's language utilization mostly by youth, although these findings do not cover translanguaging, diglossia and bidialectalism, upon which we intend to call attention.

Having reviewed international and Hungarian examples of gaming words and word formation techniques, this paper provides a detailed report about the participants, research methods and findings of our research. In the discussion part we highlight the relevance of the bilingual status of the video gamers through examples of word formation, translanguaging, diglossia and bidialectalism.

\section{Literature review}

The action video games have an enhancing effect on neural growth by requiring players to communicate in foreign language sentences, keep track of several on-screen moving items while simultaneously manipulating the controller, therefore gamers are processing the visual and auditory information successively in a fraction of a second, which "indicates [that] a relationship may exist between action video game play and multisensory processing" (Green \& Bavelier, 2003, p. 537). The gamers are also benefitting of vocabulary development to secure their language proficiency (De Haan et al., 2010, p. 74), which correlates with their inner game performance, because the more diversified their vocabulary, the greater the chance of winning at any games, and that is the greatest motivating factor for the participants (Liddicoat, 1991, p. 11). Video games in which participants must utilize a foreign language equally teach the players to process information faster in order to respond quicker. Having examined their lingual and cognitive advancement, "bilinguals were found to be significantly ahead of their monolingual counterparts in verbal and non-verbal reasoning, divergent thinking and subject matter attainment" ... "bilinguals [seem] to be more creative..." (Liddicoat, 1991, p. 19), especially, if they play video games (Baniqued et al., 2014). Besides, video gamers are required to be more inventive, a quality which helps to infer the meaning of words in context, which also accelerates their language proficiency.

\section{Video gamers and English}

In gaming the vernacular is English, by virtue of being the default language of most games, and equally a Lingua Franca (ELF) among the participants, besides, "English is ubiquitously at the top of the hierarchy of 'foreign' languages" (Skutnabb-Kangas, 1997, p. 28). Commonly, in the sports games the territorially appropriate dialect of English is spoken by the speakers, i.e. American in NBA, British in Rugby or FIFA, although the players employ rather a special, culturally non-specific, neutral form of "International" English (Stavans \& Hoffmann 2015, p. 125). 
Sociolinguists have already noticed the exploitable factors of IT and video gaming English, such as the frequently used expressions, content nouns, basic verbs, and sentence patterns. For instance, in the commonly named shooter games the simpler, yet descriptive up-to-date English is utilized, which contains several action verbs and content nouns from the spectrum of military, medical and mapping domains. The current version of English commonly used on the internet can be supplemented by language items which any gamer can develop to a quite high level of proficiency, through successful communication in various virtual circumstances.

Several expressions have been invented in linguistics to cover the phrases, abbreviations and emojis utilized by IT experts, internet communicators and video gamers for defining the subject of the particular CMC research, such as internet-slang, netspeak and new high-tech lingo (Chrystal, 2008, p. 18), chat-speak (Hilte, 2014) and gamer-speak (Strong, 2018), whereas Veszelszki (2013) introduced the umbrella term "digilect," which seems to be applicable to all kinds of CMC, and as such it has been adopted by many authors. However, the mentioned findings reveal that the video game related vocabulary is much greater than the words, abbreviations, emojis altogether, and the gamer argot is used in face-to-face verbal conversations to maximum extent. Thus, using digilect as an umbrella term seems incomplete regarding gamer argot, because the meaning lacks the possibility of its use orally in real life. Although there is an almost perfect overlap between the online and the offline gamer argot, we can discribe the online version as gamerlect in order to make it comparable to the digilect, on which the authors focus in another paper (Arnold-Stein, 2021, p. 12). Namely, we define as gamerlect the words that appear in the online gamer-gamer communication and have originally occurred in video games (ArnoldStein, 2021-in press), as a partition within the umbrella term of digilect. In this paper the offline used version filled with subcultural meanings will be identified as gamer argot.

\section{International research findings}

Chik (2014) focused of the game-based language learning and vocabulary enhancement among students living in East-Asia, who played with English, Japanese and Chinese versions of video games. Native Chinese gamers participated in the research and reported how they managed their language choices while playing and how the gaming activity aided their language learning practices. Each of the 153 undergraduate student participants had to write an autobiographical language learning history in 500 words. In the background information the players disclosed their language preferences in gaming and interestingly English was always the chosen language whenever international students were also present in the game. 
Participants also reported how they used blogs, group chats and recorded gaming sessions. Additionally, they also provided a reading jargon list extracted from game texts. This study also implies that the game-related texts in both the native language (L1) and a foreign language (L2) form the capital of knowledge for language learning.

Sylvén and Sundquist (2012) have found similar results when examining the gaming habits of 126 Swedish youth by correlating their language usage to their video gaming habits. The authors found that the video gaming is more popular than television, due to its interactivity. Spoken or written texts that are part of the informal activity of gaming also facilitate the incidental language development, acknowledged by the participants themselves. Besides, the authors concluded that the game texts were the key organiser of the participants' out-of-school language learning, because many of them also reported about the fun of new word creation and reusing the gamer ones for describing real events and circumstances. Piirainen and Tainio (2009) investigated Finnish teenager gamers to find out the role of repetition in certain games and they found frequently used in-game English expressions in out-of-game conversations as well.

Benson and Chik (2011) infer accordingly that video gaming can be considered a primary driving force in language learning for most young adolescents, based on the reports of the participants of a study in which their communicative habits were investigated. The authors noticed that the goal driven action between expert and beginner participants was promoted by communicative interactions which help to develop conversational competencies for the weaker gamers. American and Ukrainian students participated in collaborative gameplay in the World of Warcraft (WoW) and the authors noticed several L2 learning episodes, supported by safe learning periods and autonomous learning moments by immersive words.

Hilte et al. (2020) focused on the social media writing habits of Flemish Dutch secondary school teenagers, thus the authors scrutinized 1384 Facebook conversation entries shared by volunteers. They also investigated the idiosyncratic linguistic adaption and accommodation of the participants' language use and called it "chatspeak." In their conversations the participants wanted to facilitate interaction and regulate social distance by accommodating words and sentence markers, such as girls have greater preference for expressive typographic markers, like emojis or the usage of capital letters. On the other hand, the boys have used much more colloquial language and more abbreviations. The claim for social approval among teenagers is resolute, thus linguistically indicated (Gumperz, 1968, p. 469). The register depended on how the speaker would communicate face to face, which strengthened the orality maxim. Several patterns were detectable, e.g., the gamers' language utilization was much more divergent than other messages. 
Many conversations contained English expressions in a normal colloquial order and some of them were adapted to Dutch, i.e. written according to Dutch pronunciation Hilte et al., for example English words inserted into a Dutch sentence: "ben home alone nu ([I] am home alone now)" (2020, pp. 7-8); an English word written down according to Dutch pronunciation: "naais" (nice), "goed" (good); an English word with a Dutch suffix: "haar cadeaus sucken (her gifts suck)" (2020, pp. 7-8).

Strong (2018) targeted the gamer language and its possible utilization on social networks. The author narrowed his focus to the MMORPG games, in a qualitative analysis among young French gamers with special regard to what the players' motivational factors are when using special gamer language. The research focused on the system of structural differences in texts, by carrying out a discourse analysis of short excerpts selected from the written conversations. The author calls the language of the written messages "gamer-speak" in which a non-standard, fictive language creation has a conceptual generator effect on the chat room and social network conversations. The results were classified by word formation modes. The researchers found many English loans adapted to the target system. Some words had Latin origins, which means that the words (historically once of Romance Origin) were re-borrowed from English into the French language. Examples for reborrowing: mate, quest, dungeon. Examples of anglicisms: gear, hunter, tank, tool, tip; shortenings: $P \vee P, J C J, I R L$, (ro)bot, AOE; blends: healing as Healing Paladin or Healadin; composites: rebuff, hpal; raid lead (chief de raid); new creations: QQ (crying); hor2 (hordeux, horde).

\section{Hungarian research findings}

E-sports fans form a separate cast within the video game society, because such electronic games root back to real games and a considerably high number of participants do real sport activity alongside with the e-sporting (Békési \& Kovács, 2020, p. 39). Secondly, players of these types of games are most likely to become professionals, due to the growing number of e-sport events and opportunities to play for money, thus their group characteristics follow a different pattern than that of MOBA or MMORPG group members (Békési \& Kovács, 2020, p. 40). Furthermore, players of sport e-games can benefit linguistically considerably well from gaming, due to the fact that the rules of the real and the electronic versions are identical, and the sport related expressions can be reused in all walks of life. Using the same language allows the peers to adapt foreign-mostly English-sport related words into Hungarian; although they are most likely to have a Hungarian equivalent, video gamers adhere to English phrases instead, e.g. team, race, sprint, chicane, sector, DRS, from Formula 1; attack, glove, ring, ducking from boxing; foul (fault), jump, time-out, defender, block, assist, from basketball. 
Balogh conducted research in the field of gaming language use. In one of her first studies, she ran an online questionnaire that contained 9 general questions about gaming habits and 3 questions related to gaming vocabulary (2014, p. 48). 55\% of the 104 Hungarian participants admitted to being gamers. $44 \%$ of the respondents were women. The video gamers can be subgrouped into hard-core and casual gamers, depending on who plays more frequently, and which type of game, thus the members of a subgroup are aware of the coinciding expressions from the same type of games (2014, p. 46). The respondents replied positively about group language and all confirmed that the casual gamers have limited familiarity with gamer jargon (2014, p. 48). Respondents recognised $71 \%$ of the game related words, because they have overheard some expressions from other gamer friends (Balogh, 2014, p. 49). She concludes that youngsters are open to exert to utilize themselves unusual words or expressions.

Balogh and Veszelszki (2019) researched the linguistics role of the "taunts" in the League of Legends (LoL) game. Pre-written insults are kept in a phrase bank, a possibility for the players to write or say acceptable disturbances, in the heat of the game, in order to deteriorate the enemy. The authors analysed these sentences because the examples are perfect to scrutinize the latest linguistic modifications made by gamers. It is utmost important to understand the pragmatic language use from the context in order to find out the motivating factors in the communication (2019, p. 92). Gamers usually establish cooperation among peers, whereas such purposeful expressions used by the enemy, even in a polite way, can offset the communication within the group. Thus, the taunt plays a tactical role in a game, like a game within the game (2019, p. 93), it has a kind of ludic function, namely, losing a cool head can yield to lose the game. Besides, by using such aural and written tactics, the gamers can enlarge the spectrum of their communication, eventually they can have retroactive contributions. Examples: "she failed her ult, Iol" (she failed [to use] her ultimate ability, laugh out loud); "So be it ... summoner ... You will lose" (So be it player, you will lose); "her Q has big dmg" (by hitting key Q, she can cause a big damage) (Balogh \& Veszelszki, 2019, pp. 98-99).

\section{Foreign expressions in a sentence}

From a pragmatic point of view, chat room or social network communication is not exactly written language, it is rather a "written-spoken" language (Márku \& Bartha, 2015, p. 158). As a result, differently pronounced phrases and written onomatopoeic terms are very frequent as well as new word creations (Keszler, 2000). The word formation processes are the most interesting part, words are created and modified by the users regardless of grammatical or orthographical rules (Fazakas, 2015, p. 111). 
Attempting to analyse expressions grammatically requires placing them into a current organization of any discourse, namely which foreign expressions play pragmatical roles within a clause. Also, it is necessary to know the size the domain covers (i.e. game type) and the similarity of mental functioning of the interlocutor and the receiver (i.e. casual or hard-core gamer), which is deductible from the similarity of their speech patterns and seriality (Kugler, 2015, p. 16). Normally, the patterns are bonded in the in-the-game conversations (gamerlect), compared to an out-of-game discourse (gamer argot), where the patterns are loose or there is no pattern at all. Besides, in an out-of-game discourse the game related expressions are used to interpret events as they would be in a game, thus the connotation of such phrases is evoked by the interlocutors' intention. The pragmatic intention constructs different frames with grammatical strata (Langacker, 2006, p. 17, 21 cited by Kugler, 2015, p. 21), by which sentences are being elaborated from the basic to the most complicated ones. The verb functions as the organising principle in a sentence, and because the verb is usually in Hungarian, but the sentence frequently contains proper or concrete nouns, few adjectives in English, all sentences are bilingual.

Example sentence': (verb, English, -inflection)

Flame tongue Weapon/Totem 50\% helyett 25\% healing reduction-ös rebuff-ot ad, kétszer stack-el, a rebuff ugyanúgy 5 sec-es marad.

"Flame tongue (sword) weapon/totem gives (only) 25\%, instead of 50\% healing reduction rebuff (decreased healing), (if s/he) stacks (gets) twice, the rebuff (lasts for) 5 seconds."

\section{Translanguaging by video gamers}

The specialized vocabulary that characterises the language practice of the video gamers is composed by initiating various linguistic features provided by different games or linguistic modes also prompted by games. Such language utilization can be considered similar to translanguaging (Garcia, 2009), because during a gamer-gamer conversation the game jargon makes maximum sense, even in non-game related topics. Translanguaging arises when a participant relates the vocabulary of a particular game to another type of game or uses it figuratively in an instance of reality. Gamers can liberate the possibilities of translanguaging by the extent of which they are mutually familiar with the games in a conversation (Li, 2018, p. 12), by inserting foreign (English) phrases into different contexts in order to extend their connotations. In translanguaging there is no hierarchy between the occurring languages, they are all interrelated, due to the fact that the name of a particular item makes sense in L2 only for an individual or in the community (Garcia, \& Li, 2014, p. 20).

\footnotetext{
${ }^{1}$ Example sentence is from gamer365.hu website.
} 
Translanguaging also scaffolds expressive and transformational language modes in which the conversational modes are also changing through the multilingual terms (Garcia \& Li, 2014). Consequently, the edification of the gamers depends on the deployment of each speakers' repertoire in order to learn and develop from each other in the ways of extending language knowledge and equalize distances of language practices (Garcia et al., 2006, p. 14). Such situational language usage in which two languages are used in different circumstances within a population, often by the same speakers, can be called diglossia (Ferguson, 1959).

\section{Diglossia in the video game argot}

Diglossia is seen as a kind of bilingualism in a community in which there are varieties of a language with different prestige (Gvozdanovic', 2014, p. 4). There must be a substantial body of literature that incorporates the essential values of the speech community (Ferguson, 1959, p. 236) which is perceptible in the aforementioned video gaming examples. Ricento, an author of books of language policy and political theory, also argues that there are languages within a language which have a "socially constructed hierarchy, indexed from low to high" (2012, p. 34). Therefore from a sociolinguistic perspective, related to the video gamers, anyone who can apply the gaming jargon properly is accepted by the members of the subculture, as the idiomatic sign of their affiliation. Its spheres of use involve informal, interpersonal communication, i.e. conversation among friends, game opponents and possible business associates. Comparing the hardcore and the casual gamer elocution, a kind of symbolic value is also observable which shows their common root. More specifically, the hard-core gamers who use English gaming terms frequently utilize the high variant of the diglossia in which they often operate with the game specific connotations in their utterances that cannot be interpreted in L1, whereas the casual gamers speak the low variety, because they use fewer game related English words. The video gamer vernacular is virtually written in chat rooms and social media sites, thus that diglossia can be easily scrutinized.

Differences among hard-core gamer subcultures are minor, due to the fact that the gamers are eager to understand each other while gaming, thus their in-game use of phrases is identical, although their out-of-game way of speaking could deviate by topical area. The broadcasted version of the gamer argot spoken by the hard-core gamers has got the high prestige, it is also formalised, although its forms are often filtered by certain game types which are not introduced to the public. Understanding such formalised gamer argot can be considered as status symbol (Adler, 1977, p. 89), because such knowledge requires a broad comprehension of the video games that can be materialised in the job market. 


\section{Bidialectalism in the video game argot}

Moreover, there are differences also in pronunciation, the regular use of two or more dialects or diglossia of a language by a person, is called bidialectalism within a speech community (Hazen, 2001, p. 85). Often one of the two is the standard dialect and the other one is a region or culture specific dialect; in this case such dialectical differences can be caused by the English phrases in the video gaming vernacular. The more English phrases are used in the speech the bigger the chance to speak dialectically, because English pronunciation differs considerably from the Hungarian one. The differences are not regional, rather they are cultural and can be traced back to the aforementioned hardcore and casual gamer dichotomy, i.e., the hard-core gamers utilize far more English words than the casuals. Therefore, the hard-core gamers have greater chance to utter English words properly, although they also have a likelihood to play game sessions with people with harsh accents. On the other hand, this phenomenon is not really typical among the non-native English video gamers.

\section{Study}

The video gaming expressions are being used more frequently nowadays, since the number of the active gamers is growing, and the classic game specified parlance mostly used by hardcore gamers at various out-of-game communication. Such video gamer parlance occurs in several social network comments in written forms or podcasts or real-life conversations in audio forms, thus can be examined efficiently. According to our hypothesis, there are traceable effects of the video gaming on a secondary school students' online and offline conversational habits with special regards to translanguaging, diglossia and bidialectalism.

\section{Research questions}

For our study the following research questions have been formulated:

The main RQ:

Do casual gamers understand hard-core gamers' speech?

The subordinate RQs:

1. If yes, to what an extent?

2. Is there any recognisable hierarchy in a hard-core gamer's speech?

3. Can a hard-core gamer recognise dialectal differences in an unknown gamer's speech?

4. Is there any motivational factor for the casual gamers to understand the hard-core gamers' speech? 


\section{Location and participants}

First, we complied as many game related words and phrases we could from gamer365.hu blogsite and KjúbCast gamer podcast site for quantitative research purposes. Students from secondary schools in Kalocsa helped to group data by game types in order to gain a measurable amount of data for an online survey. The game type groups were the following: The League of Legends from MOBA games, The Walking Dead-(Telltale) from adventure games, and FIFA and F1 from sports games. We have differentiated the word material by game types in order to be able to acquire a broader view of both hard-core and casual gamers, because they were more likely to come across a familiar word.

Through the school IT system an anonym online questionnaire form was administered in order to reach many students with different backgrounds, hence the chance was higher to get a more accurate linguistic picture. The research proceeded from January 2021 to March 2021 and 136 participants answered the survey. The respondents were 9 to 12 grader students, ranging between 14 to 18 years old. The distribution of the gamer to the non-gamer was: 35 hardcore, 58 casual gamers and 43 non-gamers.

\section{Survey}

From the gamer365.hu we collected 692 sentences, from which the students enlisted 922 phrases and divided them into the 3 declared game types. We eliminated proper nouns, such as the names of the places or figures, F1 races, or teams, in order to promote the more frequently and commonly used words, namely concrete nouns, verbs or adjectives. After pre-categorization, we allocated 60 word-families from each game category $(3 \times 60=180$ items), which consisted of nouns, verbs and adjectives equally disseminated from levels A2-B2. We used a Likert-scale type of survey. In this light, the respondent marked 1) if the word was unfamiliar; 2) if it was familiar; 3) if it was understood and used. If the answer was 3), i.e. understood and used, the respondent was asked to give examples for the reference of the usage, either just a collocation or a whole sentence.

\section{Qualitative part}

Having evaluated the surveys, we continued with the qualitative part of the study by interviewing the hard-core and the casual gamers in order to find some examples that could be accounted for assessing the gamer argot linguistically. We were able to connect with 26 hard-core / casual gamers out of 93, via varied online video chat applications. 
In our conversations, which were carried out following the logics of the research questions, we received verbal confirmation of their examples written in the survey. There was no strict timeframe for the interviews; some of the participants explained their examples without providing any comment related to the reasons of the usage. Others, luckily, told a real story to illustrate the reasons behind their choice of certain words or sentences structures. Regarding the hardware usage of the players, hard-core gamers use mostly desktop computers at home, besides they also play on their smartphones extensively while not at home. Casual gamers use laptops and smartphones respectively. The difference between the two groups is in the speed of the internet feed-with special regard of the "ping-time" (less than $30 \mathrm{~ms}$ is the ideal, which can only be provided through optical cables)-, because the hard-core gamers need a steady and prompt internet feed-quicker than $50 \mathrm{Mbit} / \mathrm{sec}$-in order to play online for instance a shooter game. All hard-core gamers that we interviewed play on PS platform as well, but not necessarily for the time of the interviews. All the interviewed players were members of a local gaming group, which focused on the COD game by forming 3 or 4 teams occasionally, and the PS games were not fashionable among them. Since the video game industry is not any more a partition of IT, rather it is part of the entertainment industry, thus all kinds of hardware can offer gaming experience on a different level. However, from a linguistic point of view, the PC offers much broader communication options, like typing besides talking, a feature which is also available on smartphones, but not on PS or Xbox platforms.

\section{Conclusions from the written examples}

Our main goal, apart from answering the research questions, was to approach the gamer argot from a different linguistic angle, to seek cases that prove whether gamer argot can be considered an example of translanguaging, diglossia or bidialectalism. As we have collected both written and oral instances as well, we could draw conclusions of the linguistic management of the video gamers with regard to the sociolinguistic behaviour of the gamer argot. We have collected several instances of word formation methods, such as clipping ("bot" from robot), acronyms (WoW from Word of Warcraft, COD from Call of Duty) and neologisms like eponyms ("Kazuár" from the word 'casual' because they are pronounced almost similarly). The greatest group is the morphological derivations to which most examples belonged. The morphological derivation can be subdivided further according to the behaviour of the stem because the Hungarian gamers can use affixation in two ways, either, by keeping the English pronunciation of the base word or pronounce the base word as if it were Hungarian. Thus, we grouped based on the results with the pronunciation, as first in order of importance. 


\section{Keeping the original (English) pronunciation}

First we display examples of single words or collocation without affixation, which are a clear illustration of all three viewpoints. Translanguaging happens because an L2 word is used in an L1 sentence with the same or rather with extended meaning, since each phrase carries a game related meaning which sometimes differs from the literal meaning of a word. In instances of genuine translanguaging, usually a third party will join the communication to elucidate the meaning of the word, unknown or unfamiliar to one of the two players. In these cases, the words are used for the most part figuratively. Keeping the English pronunciation supports the high variety of the gamer argot, because the utterer must possess high-level language proficiency, otherwise the s/he would not be able to provide a correct pronunciation of the jargon. This phenomenon could be considered as a primary element of the gamer diglossia. Using simultaneously two languages or varieties, which are different in pronunciation, is undeniably an example of bidialectalism, because in these instances the Hungarian utterer, though not perfectly, but articulates the words following English pronunciation patterns.

Below there are some examples of the most frequent gamer words used according to the English pronunciation in a Hungarian gaming event.

"Off topic" for touching on another topic; "damage" for damage; "alpha version" for internal testing of a game; "bigdata" for personal data collected by tech giants for selling; "flag" capturing the flag online in a time-based game; Merre vagy mate? (Where are you mate?) for mate; "frag" for killing; "cringe" for being embarrassed instead of another person; "gameplay loop" for a repetitive activity in a game; "med kit" for medical kit or tools (also example for clipping).

The pronunciation of acronyms usually follows the English rules and as such might be considered as an example of translanguaging, as this pronunciation infers that the original concepts expressed by words are also cognitively present, thus they are not just a meaningless arbitrary combination of letters.

"EZ dolog" [i: zi], (easy thing) for something is easy; "TP-haza" [ti: pi:] (go home) meaning let's go); "hú de op" [o: pi:], for a very talented person. The acronym TP comes from a Hungarian slang word "tipli," normatively a non-word, meaning "let's get out of here, very quickly." This acronym has gained its rightful place in the gamer argot, naturalized in the Hungarian context to mean "let's end this game and go home!" 
Affixes often support the presence of bidialectalism. The examples are taken from context; thus, the Hungarian inflection is visible. In addition, all prefixes and/or suffixes assimilate to the stem in order to make the pronunciation smoother.

"Hipe-olták" for forced publicity; "dodge-olsz" for to dodge a blow; "unity-ben" for creating a new online default "game generating" engine something; "ki-rage-el" for to burst out; "pixel-es vagyok" (I am pixelated) for the internet feed is slow or the person is tired; "adj shield-et" (give me a shield) meaning help me; "adj bandage-ot" (give me bandage) meaning help me; "valami off-os" (something off-like) meaning anticipated loss; "ki-lootolom a hütőt" (I am looting the fridge) for taking stuff out of the fridge; "upgrade-elek" (I am upgrading) meaning to learn in order to be better in something; "raid-eljük a boltot" (let' raid the shop) meaning many people go into the store to buy some food; "quest-eljük a boltot" (let's conquer the shop, for the same meaning above); "jönnek a bot-ok" (the bots are coming) the word "bot" derives from "robot" and is a short for non-gamers; "freemiumnak látszik" (looks like a free game) meaning just the opposite; "help-elj" (help me) literary meaning; "skip-peljük a napot" (let's skip the day) meaning everything is boring; "ki-clickkeltük az embert" (we have clicked out of the man) meaning to avoid meeting somebody; "adj boost-ot" (give me a boost) asking again for help.

\section{Affixation by the Hungarian pronunciation}

In case of English words already adapted to the Hungarian pronunciation we might not talk about the bidialectalism. Nevertheless, translanguaging and bidialectalism are also implied since the words have originated in a foreign language and such phrases are used with a video game connotation.

"lement a HP-ja" [h^ pe:], (his/her health points went down), meaning lost interest or feeling tired; "attack-oljuk a boltot" [atak], (let's attack the shop) meaning buying food in a shop; "lag-golok" [lag], (I am lagging) for a momentary lapse in the game flow; "ki-bannoltuk az embert" [ban], (we have banned the person) meaning to; "warn-ollak" [varn], for warning; "TK" [te: $k \wedge$ ], for team kill, bad things have happened in a row.

Interestingly, there are also examples of acronyms that do not follow an English pronunciation pattern, even if the gamers are familiar with the concept and would be expected to use their original pronunciation. By way of analogy, we suppose that English acronyms that were introduced into the Hungarian common language usage earlier and were pronounced according to the Hungarian phonetic (e.g.: DVD, CD, SMS, MMS, etc.) might just as well exert their iconicity in pronunciation for the new acronyms as well. Another possible explanation for pronouncing NPC [en pe: ce:] for Non-Player Character, 
DLC [de: el ce:] for downloadable content, MVP [em ve: pe:] most valuable player according to Hungarian rules could be that influencers naturalized these acronyms while playing and as such there are no normative linguistic rules determining which acronyms keep their original pronunciation and which follow the Hungarian one. It has also been observable that the Hungarian pronunciation is much more common in the casual gamers.

Clipping English words and adapting their orthographic representation to meet Hungarian pronunciation rules is a very common process of linguistic adaptation and naturalization in the world of gaming. Later on, these words enter the common Hungarian lexis.

"Soti" for shotgun; "szeró" for server; "maxos" for ultimate.

The conversational examples below have been written by gamers.

Ebből a loot-ból veszek a soti-ra egy upgrade-t, hogy nagyobb legyen a damage.

"I have looted some stuff from which I can buy some upgrade to make bigger damage with my shotgun."

Elcsesztem a flag-em, mehetek vissza a hill-re.

"I screwed my flag, now I must go back to the hill."

Kaptam egy boost-ot a mate-től, így már sikerült behúznom pár frag-et, aztán elkezdett lag-golni és kidobott a szeró-ról.

"I had got some boost from the mate, so I was able to gain some frags, then (the game) started lagging and got me out from the (game) server."

\section{Answering the research questions}

Summing up, out of 180, 154 (85\%) word families were marked as "understood and used" by hard-core gamers; 28 (15\%) different words or collocations were marked as "understood and used" by casual gamers whereas non-gamers marked 17 (9,4\%) words as "understood and used." Participants recognised mostly nouns, fewer verbs and only a few adjectives. The hard-core gamers also contributed with 150 collocations altogether on their surveys, casual gamers contributed with 35 words and collocations, which they thought could be derived from any video game, because they overheard or oversaw them from the communication of their hard-core gamer friends.

Our main RQ, namely:

"Do casual gamers understand hard-core gamers' speech?" can be answered positively, with the remark that, only to a small extent, because a hard-core gamer frequently embeds English or other game related words, for instance Japanese words from Pokémon game, into her/his speech. 
Answers to our subordinate RQs:

1. If yes, to what an extent?

$15 \%$ of the cases are comprehensible for the casual gamers when they listen to a hard-core gamer. According to all of our interviewees, it depends on what kind of games the casual gamer plays and with whom, consequently the linguistic circumstances and the personal interests are the most important factors, which deserves further research.

2. Is there any recognisable hierarchy in a hard-core gamer's speech?

According to the opinion of the casual gamers, hard-core gamers who can earn money and prestige through video gaming or making podcasts about games, have attained a significant level of English. These gamers form a special linguistic cast, and their existence is very encouraging, as the level of their English knowledge as well as their different competencies at lexical and grammatical level serve as a role model to casual players, some of whom have even expressed their inner motivation to attain a similar high level of English as one of the outcomes of playing.

3. Can a hard-core gamer recognise dialectal differences in an unknown gamer's speech?

They can tell from which country the player in question comes from. After several years of video gaming and involvement in virtual fights, gamers can identify the background of a gamer by her/his accent.

4. Is there any motivational factor for the casual gamers to understand the hard-core gamers' speech?

Yes, there are several factors such as the goal to play more types of video games, to acquire a higher-level competence in English and to belong to a certain well delimited gamer group. The affiliation of the gamer to the given subculture is idiosyncratic. The real habitat of the video gamers is in the virtual reality.

The non-gamers marked as recognised several words and expressions, as were familiar with them from their online activities. Out of 93 gamers, we were able to interview 26, whose answers corroborated and provided 
circumstantial descriptions on what the best way to monitor a gamer-gamer conversation would be and how the gamers could overhear and learn these gamer argot items. The most specifically indicated places were on the morning bus, at the bus stop, in the school corridor or in the classroom.

\section{Conclusion}

The everyday language use is impacted by different influencing communication channels, such as social media sites, television, and video gaming, in which the language use has been changing rapidly. Linguists must keep an eye on such influencing areas, otherwise we will miss to realize the reasons of the latest linguistic changes. We hope that our findings direct the focus onto the utilized languages of the virtual world, with special regard to English. Although our questionnaire was limited to the students of the city of Kalocsa, we were able to find many examples to support our hypothesis.

Our findings attempt to shift more intensive attention to the necessity of deeper research in the field, because translanguaging, diglossia and bidialectalism have not been analysed and discussed thoroughly in relation to video gaming before. Word transition between English and Hungarian is an ongoing and accelerated process, due to the swift increase in a gamer's glossary in Hungary, from which words are being used more frequently by hard-core and even some casual gamers. The internet fosters the transfer of gaming language chunks into the spoken and written vernaculars, with the latest trends visible currently in all walks of life, just think of the frequency of using the words virus, mask, pandemic in the past few months. As a final conclusion we may argue that the gaming argot has been growing steadily in Hungary since the turn of the new millennium and has contributed beneficently to the development of English language competence in teenagers and young adults. Besides, video gaming is not just about playing games per se, it is rather a lifestyle in which the participants are frequently communicating with each other for seeking information, help or partner for a particular game or event. In terms of accurate language use, the members sometimes use incorrect orthography and less complex sentences while chatting, because comprehension is in focus. Nevertheless, relying on a more communication competence and confidence, all gamers are motivated to consciously develop a more fluent language use in order to increase their opportunities in the virtual world. The current research projects the further investigation of new instances of linguistic competences in gamer communication with special focus on grammatical, socio-linguistic and expository competences. 


\section{References}

Adler, M. K. (1977). Collective and individual bilingualism: A sociolinguistic study. Helmut Buske Verlag.

Arnold-Stein, R. (2021). The hungarian video gamers' English phraseology and its enriching effect on the hungarian linguistic diversity. $28^{\text {th }}$ Congress of the Association of Hungarian Applied Linguistics (XXVIII. Magyar Alkalmazott Nyelvészeti Kongresszus, Veszprém) (online), 19-20. April 2021.

Balogh, A. (2014). Geeknyelvtan? A számítógépes játékok nyelvéről. In Veszelszki, Á., \& Lengyel, K. (Eds.), Tudomány, technolektus, terminológia. A tudományok, szakmák nyelve (pp. 345-352). Éghajlat Könyvkiadó.

Balogh, A., \& Veszelszki, Á. (2019). Udvariasság és sértés a számítógépes játékokbanpragmatikai szempontból. Magyar Nyelvőr, 2019/1, 88-116.

Baniqued, P. L., Kranz, M. B., Voss, M. W., Lee, H., Cosman, J. D., Severson, J., \& Kramer, A. F. (2014). Cognitive training with casual video games: points to consider. Frontiers in Psychology, 4, 1010. https://doi.org/10.3389/fpsyg.2013.01010

Benson, P., \& Chik, A. (2011). Towards a more naturalistic CALL: Video gaming and language learning. International Journal of Computer-Assisted Language Learning and Teaching, 1, 1-13. https://doi.org/10.4018/ijcallt.2011070101

Békési, Zs., \& Kovács, K. (2020). Az e-sportolók csoportjellemzőinek feltárása. Információs Társadalom, 20(1), 29-49. https://dx.doi.org/10.22503/inftars.XX.2020.1.2

Cabraja, A. (2016). The effects of video games on the receptive vocabulary proficiency of Swedish ESL students (Dissertation). http://urn.kb.se/resolve?urn=urn:nbn: se:su:diva-131136

Chik, A. (2014). Digital gaming and language learning: Autonomy and community. Language Learning \& Technology, 18(2), 85-100. http://dx.doi.org/10125/44371

Cook, V. (1993). Wholistic multi-competence-jeu d'esprit or paradigm shift? In Kettemann, B., \& Wieden, W. (Eds.), Current Issues in European Second Language Acquisition Research (pp. 3-9). Narr Franke Attempto Verlag GmbH \& Co. KG.

Crystal, D. (2008). Txtng: The gr8 db8. Oxford University Press.

De Haan, J., Reed, W. M., \& Kuwada, K. (2010). The effects of interactivity with a music video game on second language vocabulary recall. Language Learning and Technology, 14(2), 74-94.

Fazakas, N. (2015). Language myths and ideologies in the new media. International Review of Studies in Applied Modern Languages, 8, 102-113.

Ferguson, C. A. (1959). Diglossia. WORD, 15(2), 325-340. https://doi.org/10.1080/00437 956.1959 .11659702

Frehner, C. (2008). Email-SMS-MMS. The linguistic creativity of asynchronous discourse in the new media age. Peter Lang.

García, O., Skutnabb-Kangas, T., \& Torres-Guzmán, M. (2006). Weaving spaces and (de)constructing ways for multilingual schools: The actual and the imagined: Languages in education and glocalization. In García, O., Skutnabb-Kangas, T., \& Torres-Guzmán, M. (Eds.), Imagining Multilingual Schools (pp. 3-48). De Gruyter.

Garcia, O. (2009). Bilingual education in the 215t century: A global perspective. Wiley-Blackwell. 
García, O., \& Li, W. (2014). Language, bilingualism and education. In García, O., \& Li, W. Translanguaging: Language, bilingualism and education (pp. 5-18). Palgrave Macmillan. Garcia, O., \& Kleifgen, J.A. (2018). Educating emergent bilinguals. Policies, programs, and practices for English learners, Second edition. Teacher College Press.

Gvozdanovic', J. (2014). Understanding the essence of diglossia. In Árokay, J., Gvozdanovic', J., \& Miyajimap, D. (Eds.), Divided languages? Diglossia, translation and the rise of modernity in Japan, China, and the Slavic world (pp. 3-21). Springer.

Gee, J.P. (2009). New digital media and learning as an emerging area and "worked examples" as one way forward. The MIT Press.

Green, C.S., \& Bavelier, D. (2003). Action video game modifies visual selective attention. Nature, 423, 534- 537.

Grosjean, J. (1997). The bilingual individual. Interpreting, 2(1-2), 163-187. https://doi. org/10.1075/intp.2.1-2.07gro

Gumperz, J.J. (1968). Types of linguistic communities. In Fishman, J.A. (1968). Readings in the sociology of language (pp. 460-473). Mouton Publishers.

Hazen, K. (2001). An introductory investigation into bidialectalism. University of Pennsy/vania Working Papers in Linguistics, 7(3), 85-99.

Hing, D. (2015, April 01). Four difficulty levels on how to use video games to learn English. Kaplan international languages blog. https://blog.kapintdc.com/four-difficulty-levelson-how-to-use-video-games-to-learn-english Last viewed: 28.11.2020.

Hilte, L., Vandekerckhove, R., \& Daelemans, W. (2020). Linguistic accommodation in teenagers' social media writing: Convergence patterns in mixed-gender conversations. Journal of Quantitative Linguistics, 1-28. https://doi.org/10.1080/09296174.2020.1807853

Horowitz, K. S. (2019). Video games and English as a second language: The effect of massive multiplayer online video games on the willingness to communicate and communicative anxiety of college students in Puerto Rico. American Journal of Play, 11(3), 379-410.

Hortobágyi, I. (2017a). The linguistic rhythms of urban spaces: New approaches to everyday multilingualism. TOPOS: Journal of Space and Humanities, 6(2), 97-108.

Hortobágyi, I. (2017b). Renegotiating meaning in multimodal media contexts. Synergy, Journal of the Department of Modern Languages and Business Communication, University of Bucharest, Romania, 13(1), 145-161.

Keszler, B. (2000). A szóképzés. In Keszler, B. (Ed.), Magyar Grammatika. Nemzeti Tankönyvkiadó.

Kugler, N. (2015). Megfigyelés és következtetés a nyelvi tevékenységben. Segédkönyvek a nyelvészet tanulmányozásához 179. Tinta Könyvkiadó.

Li, W. (2018). Translanguaging as a practical theory of language. Applied Linguistics, 39(2), 9-30. https://doi.org/10.1093/applin/amx039

Libben, G., \& Goral, M. (2015). How bilingualism shapes the mental lexicon. In Schwieter, J.W. (Ed.), The Cambridge handbook of bilingual processing (pp. 631-644). Cambridge University Press.

Liddicoat, A. (1991). Bilingualism. An introduction. In Liddicoat, A. (Ed.), Bilingualism and bilingual education. NLIA Occasional Paper, 2, (pp. 3-25). National Languages Institute of Melbourne. 
Márku, A., \& Bartha, Cs. (2015). Researching the internet language use as a modern trend in applied linguistics. In Huszti, I., \& Lechner (Eds). I. Modern trends in foreign language teaching and applied linguistics. Proceeding of the international conference "Modern trends in foreign language teaching and applied linguistics in the twenty-first century: Meeting the challenges", 156-168. http://www.kmf.uz.ua/hun114/images/konyvek/ modern-trends_11_17.pdf Last viewed: 05.02.2021.

Piirainen-Marsh, A., \& Tainio, L. (2009). Other-repetition as a resource for participation in the activity of playing a video game. The Modern Language Journal, 93(2), 153-169. https://doi.org/10.1111/j.1540-4781.2009.00853.x

Prensky, M. (2006). Don't bother me mom-l'm learning! How computer and video games are preparing your kids for twenty-first century success-and how you can help! Paragon House.

Ricento, T. (2012). Political economy and English as a 'global' language. Critical Multilingualism Studies, 1(1), 31-56.

Reinders, H., \& Wattana, S. (2011). Learn English or Die: The effects of digital games on interaction and willingness to communicate in a foreign language. Digital Culture \& Education, 3(1), 3-29.

Skutnabb-Kangas, T. (1984). Bilingualism or not: The education of minorities. Multilingual Matters.

Skutnabb-Kangas, T. (1997). Human rights and language policy in education. In Wodak, R., \& Corson, D. (Eds.), Encyclopedia of language and education. Encyclopedia of language and education vol. 1 (pp. 55-65). Springer.

Stavans, A., \& Hoffmann, C. (2015). Multilingualism. Cambridge University Press.

Strong, S. (2018). Gamer-generated language and the localisation of massively multiplayer online role-playing games (PhD Dissertation). University College London.

Sylvén, K. L., \& Sundqvist, P. (2012). Gaming as extramural English L2 learning and L2 proficiency among young learners. The Journal of European Association for Computer Assisted Language Learning (ReCALL), 24(3), 302-321. https://doi. org/10.1017/S095834401200016X

Veszelszki, Á. (2010). Digilektus a lektusok rendszerében. In Illés-Molnár, M., Kaló, Zs., Klein, L., \& Parapatics, A. (Eds.), Félúton 5. Az ELTE BTK Nyelvtudományi Doktori Iskolájának konferenciája. ELTE BTK Nyelvtudományi Doktori Iskola. 199-215. L'Harmattan.

Veszelszki, Á. (2013). Digilektus és netszótár. Irodalomismeret, 2013/1, 184-197.

Veszelszki, Á. (2016). A netnyelvészet terminológiai és kronológiai áttekintés (2010-2015). In Balázs, G. (Ed.), Jelentés a magyar nyelvről, 2010-2015 (pp. 56-73). Inter.

Veszelszki, Á., \& Parapatics, A. (2016). From cooperation to compassion: Death and bereavement on social networking websites. In Knautz, K., \& Baran, K. S. (Eds.), Facets of Facebook: Use and users. Series knowledge \& information (pp. 172-209). De Gruyter.

Veszelszki, Á. (2017). Digilect: The impact of infocommunication technology on language. De Gruyter. 